\title{
Biochemical response to sport related anxiety
} Biokemijski odgovor na anksioznost uzrokovanu sportskim aktivnostima

\author{
Sandra Dinter ${ }^{1}$, Dijana Detel ${ }^{2}$, Lara Batičić ${ }^{2 *}$
}

\begin{abstract}
The goal of each professional athlete is to reach maximal performance. In order to achieve that, physical as well as mental training needs to be part of a regular training routine. Anxiety significantly affects athletic performance while extreme anxiety levels are associated with reduced athletic achievements. Therefore, controlling sport-related anxiety seems to be one of the most significant aspects for elite athletes. In order to understand the biology behind sport-related anxiety, this review is focused on the biochemical responses to such a stressor. Knowing the biochemistry of stress and its limiting factors on athletic performance enables us a greater understanding of the influence of anxiety on professional athletes. It might help to better understand the importance of sport psychology and how our mindset influences our performance. Furthermore, the correlation between the placebo effect and the manner in which the mind controls the body are considered as it might prove an important tool for future athletic training and sport psychology.
\end{abstract}

Key words: anxiety; athletic performance; placebo effect; sport psychology

Sažetak. Cilj svakog profesionalnog sportaša jest postizanje najviše razine sportskih performansi. $U$ tu svrhu fizička i mentalna priprema trebaju biti dio redovitih treninga. Anksioznost značajno utječe na sportsku izvedbu a izrazita tjeskoba povezana je sa smanjenim atletskim dostignućima. Stoga je za sportaše jedna od vrlo važnih značajki sposobnost kontroliranja anksioznosti. Kako bismo razumjeli biološke odgovore povezane $s$ anksioznošću, ovaj je pregledni rad usmjeren na razjašnjavanje biokemijskih odgovora navedenog stresora. Poznavanje biokemijskog odgovora organizma uzrokovanog stresom te njegovih ograničavajućih učinaka na sportsku izvedbu omogućuje nam veće razumijevanje utjecaja tjeskobe na profesionalne sportaše. Navedeno nam daje uvid u bolje razumijevanje važnosti sportske psihologije te pojašnjava na koji način mentalno stanje utječe na fizičku izvedbu. U radu se opisuje i korelacija između placebo učinka i načina na koji um kontrolira fizičku snagu, s obzirom na to da ova saznanja mogu predstavljati važnu komponentu sportske psihologije, te daje mogućnost poboljšanja načina pripreme sportaša.

Ključne riječi: atletske performanse; placebo učinak; sportska psihologija; tjeskoba
${ }^{1}$ Medicinski fakultet Sveučilišta u Rijeci, Rijeka, Hrvatska

${ }^{2}$ Zavod za medicinsku kemiju, biokemiju i kliničku kemiju, Medicinski fakultet Sveučilišta u Rijeci, Rijeka, Hrvatska
*Corresponding author: Doc. dr. sc. Lara Batičić

Zavod za medicinsku kemiju, biokemiju i kliničku kemiju

Medicinski fakultet Sveučilišta u Rijeci, Braće Branchetta 20, 51000 Rijeka

E-mail: lara.baticic@uniri.hr 
PLACEBO AND MIND: A BIOCHEMICAL CONNECTION

The placebo effect may be defined as a beneficial effect produced by a placebo drug or treatment, which cannot be attributed to the properties of the placebo itself and must therefore be due to the patient's belief in that treatment ${ }^{1}$. Researchers have been studying this phenomenon for years trying to understand how exactly it works and how to make use of it in different scientific

Athletic performance is influenced by many physiological and psychological factors. Fine motor skills, cognitive skills, and metabolic adaptations seem to be most vulnerable to anxiety and result in reduced performance.

fields. The most prominent and discussed is the placebo effect in medical environments. Improving a patient's health or alleviating symptoms by using the placebo is a highly controversial topic. Studies show that a placebo treatment can make a big difference in a patient's health or therapy. However, the placebo effect in relation to athletic performance has not been well researched yet. It remains to be explored how our mind influences the biochemical processes in the body and to what extend this could affect athletic performance. In order to explore this question, there is a need to gain a better understanding of the placebo effect and its impact on the human body.

In 2017, a group of psychologists and mindset researchers conducted a study about the placebo response ${ }^{1}$. A total of 164 healthy adults participated in the research that tested their allergic reaction to histamine with a skin prick test. The patients were then administered a placebo cream, where the following characteristics were tested: cream effectiveness (active or inactive ingredients), warmth of the provider, and competence of the provider. The results showed that patients who believed to be treated by the active cream and perceived the physician as warm and competent showed the biggest improvement in their allergic reaction. On the other hand, those patients who believed to have been administered the inactive cream and perceived the physician as cold and less competent showed a stronger allergic reaction.
Another study that shows the direct relation between placebo or a patient's mindset and the body is the "Milkshake study "2. Here, the participants were given the same milkshake, but with two different labels, while measuring their ghrelin levels. Ghrelin, or the so-called hunger hormone, is released by the stomach after a period of fasting. It is a 28 amino acid peptide with a molecular mass of 3315 Da (purified ghrelin) that signals the peripheral nutritional status of the body to the hypothalamus ${ }^{3}$. Ghrelin levels significantly increase in the fasting state, signaling to the brain to obtain food. After a meal, those ghrelin levels drop and initiate the metabolism of the just consumed food whereby ghrelin levels are proportional to the consumed calories. In the milkshake study, the participants were given the same milkshake twice but with different labels. The first one was labeled as a low calorie "Sensible shake, $140 \mathrm{kcal}$ ", whereas the second one was labeled as "Indulgence, 620 kcal." Ghrelin levels were measured, after consuming the milkshake. The results showed that the average ghrelin concentration decrease after the second milkshake was three times larger than after the first, notifying the brain that the consumed meal was also three times richer in calories ${ }^{2}$.

Ghrelin is synthesized in the gastric oxyntic glands which are found in the fundus ${ }^{3,4}$. The ghrelin gene is located on chromosome 3p25-26 and is responsible for the synthesis of 5 different products, ghrelin being one of them ${ }^{3}$. Its mRNA is first translated into pre-proghrelin, a 117 amino acid residue. Then, a specific peptidase cleaves it into a 97 amino acid residue called proghrelin, which can now undergo a fairly complicated posttranscriptional modification. One important step is the O-n-octanoylation. Adding an octanoyl group at the serine 3 by ghrelin O-acyltransferase, is essential for future binding to its receptors. After the acylation, proghrelin gets converted into the final ghrelin by the prohormone convertase enzyme and is stored in granules within the cell ${ }^{4,5}$. The release of ghrelin from its oxyntic cells in the stomach is dependent on multiple factors. It is widely accepted that the release is inversely related to the energy state of the body ${ }^{6,7}$, however, many factors seem to influence ghrelin secretion. Studi- 
Table 1. The effects of ghrelin on specific effector organs

\begin{tabular}{|l|l|}
\hline \multicolumn{1}{|c|}{ Target organ } & \multicolumn{1}{c|}{ Ghrelin effects } \\
\hline Hypothalamus & increased apetite \\
\hline & increased food intake \\
\hline & lipid sensing \\
\hline Pituitary & increased growth hormone \\
\hline & increased ACTH \\
\hline Pancreas & decreased insulin secretion \\
\hline & increased insulin sensitivity \\
\hline & glucose metabolism \\
\hline Liver & increased IGF1 \\
\hline Intestine & increased intestinal motility \\
\hline Adipose tissue & decreased lipid oxidation \\
\hline & increased lipogenesis \\
\hline & decreased inflammation \\
\hline
\end{tabular}

\begin{tabular}{|l|l|}
\hline \multicolumn{1}{|c|}{ Target organ } & \multicolumn{1}{c|}{ Ghrelin effects } \\
\hline brain areas & taste sensation \\
\hline & reward behavior \\
\hline & olfaction and sniffing \\
\hline & learning and memory \\
\hline & depression \\
\hline & sleep/wake cycle \\
\hline Sympathetic NS & decreased SNS activity \\
\hline Heart & increased cardiac output \\
\hline & increased contractility \\
\hline & vasodilation \\
\hline Stomach & increased gastric emptying \\
\hline & increased gastric motility \\
\hline & increased gastric acid secretion \\
\hline & \\
\hline
\end{tabular}

es show that somatostatin, fatty acids, and insulin have an inhibitory effect on the endocrine cells, whereas low D-glucose levels and norepinephrine have a positive effect ${ }^{6-9}$. Insulin, named as the most relevant regulator, inhibits ghrelin release by suppressing its mRNA expression via a cAMP pathway and in an inverted u-shaped manner ${ }^{7}$. In addition to the mentioned factors, available research data imply that the autonomic nervous system could also affect ghrelin release ${ }^{7}$, but further studies need to be performed in that area.

Secreted ghrelin then binds to the growth hormone secretagogne receptor type 1a (GHSR-1a). This is a $\mathrm{G}$ protein-coupled receptor found mainly in the hypothalamus and pituitary gland and is responsible for the growth hormone release ${ }^{3-5}$. Besides controlling food intake, ghrelin also shows a variety of effects on multiple peripheral organs as shown in table 1.

The above-mentioned placebo-related studies show that placebo treatments can influence hormone levels and biochemical reactions, thereby proving that our mindset and our perception have direct impact on our body's biochemical pathways.

\section{SPORT PSYCHOLOGY AND ITS INFLUENCE} ON ATHLETIC PERFORMANCE

In all competitive sports, the goal is to achieve maximal performance. In order to accomplish that, professional athletes know that training their mind is just as important as training the body. However, the athletic community is still hesitant to use sport psychologists as a constant part of their training due to the socially perceived stigma related to psychological treatments. Chris J. Gee ${ }^{10}$ highlights the importance of sport psychology by emphasizing the significant differences between athletes based on their mental capacities. He clarifies that athletic performance is not just dependent on genetics but also on other factors. Gee calls it the "relative" and "absolute performance", with absolute performance being the theoretical ideal of athletic capacity one has, based on genetics that are beneficial for certain sports. On the other hand, the relative performance represents the actual outcome of an athlete's capacities, and includes all other factors influencing the athletic results. Those could be internal factors like an illness, improper nutrition, fatigue, or psychological pressure like expectations or anxiety, or external ones like spectators, weather, or game officials.

\section{INTRODUCING ANXIETY}

The focus of this review is on anxiety and how it relates to athletic performance. Anxiety may be defined as "cognitive concerns/worry and autonomic responses that accompany a stressful situation, particularly when the perceived situational demands exceed the individual's perceived ability to meet those demands and successful perfor- 
mance in the activity is important to the individu$\mathrm{al}^{\prime 10}$ and is considered to be one of the most influential factors when it comes to athletic performance. Whereas small amounts of pre-competitive anxiety are said to be performance enhancing ${ }^{10}$, being overly anxious usually impairs an athlete's abilities. Reducing anxiety, therefore, directly relates to a better athletic performance. Mental training, meditation and awareness practices are tools often used to control sport-related anxiety. Dehghani et $a^{11}$ explored the effectiveness of the so called Mindful-Acceptance-Commitment (MAC) technique in athletes. MAC is a program consisting of 8 sessions that target body awareness, breathing, goal assessment, and other mental training tools. The results of that study showed a significant reduction in anxiety and improvement of athletic performance.

While much research has been done showing the correlation of anxiety and athletic performance, with the above-mentioned MAC study representing just one of them, it is usually approached from a psychological point of view. Therefore, this paper places an emphasis on the biological aspect of it by looking at the influences of anxiety on the biochemical level. Even though it seems like the correlation between anxiety and physical performance is an area that leaves great potential for further studies, certain correlations have already been made.

Crewther et $a l^{12}$ showed that increased cortisol levels, which are a result of the stress response, in combination with low testosterone can improve muscle strength. Other literature suggests that a reduction of cognitive input could improve performance as well, since incoming signals are focused on the most significant information ${ }^{13}$.

Other studies show that anxiety or short-term stress can increase the memory function if the stress level is low enough but decrease memory function if the stress level is too high ${ }^{14,15}$. Stress intensity and memory function relate with an inverted u-shaped graphic, where low acute stress increases long term memory formation due to the stress hormones and their interaction with the amygdala ${ }^{14}$.

If the stress intensity relates to memory function as an inverted u-shaped graph, it is suggested that it relates in the same way to physical performance. Therefore, exploring the effects of sympathetic stimulation in more detail could reveal the causes for altered physiological mechanisms and decreased athletic performance.

It is well known that long term stress lowers physical performance ${ }^{16}$; could the same hold true for intense short-term stress, i.e. sport anxiety?

\section{BIOCHEMICAL RESPONSE TO ANXIETY}

Anxiety and fear are emotions we feel when threatened. The danger can be real, e.g. in an encounter with a wild animal or some other life-threatening situations. It can also be internally perceived, e.g. if a person is anticipating an unfavorable outcome of a situation. However, both emotions activate the sympathetic part of the autonomic nervous system ${ }^{17}$. Even though their perception and stimuli might differ, the physiological response to them is the same. They trigger a complex stress response: activation of the amygdala, the hypothalamic pituitary adrenal axis (HPA), and influence other endocrine and physiological factors such as respiration, cardiovascular functions or blood glucose levels, all effectors of the fight and flight response ${ }^{16,17}$. If the brain senses stress, the amygdala is activated as part of the sympathetic stimulation. In response, the amygdala stimulates the hypothalamus and activates the hypothalamic-pituitary-adrenal axis. Cortico-releasing hormones ( $\mathrm{CRH}$ ) are secreted by the hypothalamus and, in turn, trigger the adrenocorticotropic hormone (ACTH) secretion from the anterior pituitary gland. ACTH is a major hormone in the stress response because it activates the adrenal cortex and results in the release of glucocorticoids (GCs), like cortisol ${ }^{17}$. Additionally, sympathetic stimulation also causes the adrenal medulla to release catecholamines.

\section{PILLARS OF ATHLETIC PERFORMANCE}

Athletic performance is influenced by many physiological and psychological factors. Lung capacity, cardiovascular capacity, muscle strength, fine motor skills, cognitive skills ${ }^{18,19}$ and metabolic adaptations are just a few of them. Fine motor skills, cognitive skills, and metabolic adaptations seem to be most vulnerable to anxiety and result 
in reduced performance. Therefore, a detailed understanding of those mechanisms in response to sympathetic stimulation is necessary.

\section{Fine motor skills}

One important parameter of excellent athletic performance are good motor skills. Athletes train specific movements, characteristic for their sport, and perfect their fine motor abilities. Increased stress or anxiety can diminish those fine motor skills and result in a decreased performance.

One factor that decreases performance is an increased muscle tension related to high stress levels. Lundberg et $a l^{17}$ state that stress activates low threshold motor units and increases the muscle tension even without any workload. Over time, an increased muscle tonus could cause nutrient depletion and the accumulation of waste and inflammatory substances, which then lead to stiffness ${ }^{20}$.

Other studies suggest that increased stress and the resulting increase in plasma catecholamines has a significant effect on skeletal muscle as well. Epinephrine and norepinephrine bind to $\beta 2$ adrenergic receptors and could increase muscle tension in two ways. On the one hand, they could act on the presynaptic terminal of the neuromuscular junction and increase vessel exocytosis and, therefore, increase the acetylcholine excretion, which stimulates contraction. On the other hand, $\beta 2$-adrenergic receptors have an effect on ryanodine receptors and, consequently, enhance the calcium release from the sarcoplasmic reticulum, increasing contractility as well ${ }^{21}$.

There does not seem to be one universally accepted mechanism for stress-induced muscle tensi$o^{22}$, but an increased tension in the resting state certainly interferes with the fluidity of motor unit recruitment and results in decreased motor skills. Furthermore, the stress response causes stronger and more energetic movements due to sympathetic activation, which comes at a cost of precision $^{17}$.

Additionally, fine motor skills seem to be interrupted by the stress hormone cortisol. The cortical and subcortical motor centers of the brain have type 2 glucocorticoid receptors (GRs) that can react to the fight or flight induced hormones cortisol, corticoreleasing hormone (CRH) and $\mathrm{ACTH}^{23}$. An increase in those stress hormones increases the binding to GRs and, consequently, affects motor functions.

GR type 2 is a ligand-dependent receptor and part of the nuclear receptor superfamily, which regulates gene transcription. All GR subtypes are created by posttranscriptional modification and originate from a single gene ${ }^{24}$. In the classical pathway, cortisol enters the cell and is either inacti-

There does not seem to be one universally accepted mechanism for stress-induced muscle tension, but an increased tension in the resting state certainly interferes with the fluidity of motor unit recruitment and results in decreased motor skills.

vated into cortisone by $11 \beta$-Hydroxysteroid dehydrogenase type 2 (11ß-HSD2) or kept active/ reactivated by $11 \beta$-hydroxysteroid dehydrogenase type 1 (11 $\beta$-HSD1). Active cortisol can then bind to the GR type 2 receptor in the cytosol of the cell and initiate its conformational change. At that point the newly structured GR can now enter the nucleus via nuclear pores, where it controls gene expression ${ }^{24}$. Since this pathway changes cellular activity based on gene expression, it needs more time and acts over a period of minutes or hours. Therefore, a second pathway of intracellular signaling without gene alteration is proposed ${ }^{24,25}$. This alternative pathway reacts within seconds or minutes ${ }^{25}$ and explains fast cortisol-initiated response mechanisms. Since glucocorticoid receptors act similarly to steroid receptors in the peripheral body, it is argued that they show similar functions in the brain. Therefore, they are likely to be translocated to the cell membrane in the alternative pathway and build larger complexes with other receptors, like g-coupled proteins, to start a signal cascade. Four major cascades are suggested 1 ) phospholipase $C$ - protein kinase C pathway, 2) cyclic AMP - protein kinase A pathway, 3) Phosphoinositide 3-kinase (PI3K) - protein kinase $B(A k t)$ pathway, and 4) rat sarcoma protein (Ras) - extracellular receptor kinase (ERK) pathway ${ }^{25}$. 
Metz et $a^{23}$ investigated the relation between the stress hormone corticosterone (glucocorticoid in rodents) in rats and its effect on accurate reaching performance and limb coordination. Corticosterone levels were increased via oral ingestion as well as stressor induced. The experiment showed a significant correlation between hormone levels and motor functions, where elevated corticosterone levels significantly reduced the accuracy of reaching performance as well as limb coordination. Additionally, the study showed that not only elevated corticosterone but also other stress-induced mechanisms, like emotional changes, alter motor functions.

The precise relation between cortisol and the motor function have yet to be determined. However, there is promising research that shows a potential connection. Parkinson studies have shown that stress increases neuronal loss and exacerbates motoric symptoms such as tremors, rigidity, bradykinesia and skilled movements in Parkinson patients ${ }^{26,27}$ therefore, suggesting a first link between the stress response and the motor system. Elevated cortisol levels were also measured in Parkinson patients, highlighting a link between glucocorticoids and the dopaminergic system. Metz ${ }^{27}$ indicates that stress activates the dopaminergic system and leads to "locomotor hyperactivity", which is coherent with the increase in movement due to sympathetic stimulation mentioned earlier in this paper. Furthermore, results of the above mentioned study also suggest that an increased release of dopamine results in a lack of dopamine due to insufficient replenishment, which could negatively influence fine motor skills since dopamine is an important neurotransmitter in motor pathways of the brain. The mechanism of how cortisol influences dopamine in the motor pathways has yet to be determined but a study from 2017 by Wheeler et $a^{28}$ shows its influence on reward systems of the brain and could indicate a promising connection. This research on male SpragueDawley rats showed that stress-induced corticosterone (cortisol equivalent in rodents) causes an increase in extracellular dopamine in the nucleus accumbens as part of the reward circuit in the brain. Using a fast-scan cyclic voltammetry, he showed that the increase in extracellular dopamine was due to an increased dopamine release from the neurons. Increased dopamine levels in response to stress-induced cortisol/corticosterone secretion in the reward circuit hypothesizes a similar connection for the motor system. In summary, many cortisol sensitive GRs sit in motor centers of the brain. As seen in Parkinson patients, increased cortisol levels aggravate motoric functions and, therefore, indicate a connection to the dopaminergic system. Wheeler et $a^{28}$ noted that an increased extracellular cortisol can lead to an increased dopamine release, which then could result in dopamine depletion; this, according to $\mathrm{Metz}^{27}$, decreases fine motor skills.

Since the dopamine release is not only dependent on incoming action potentials but can also be influenced by Trace Amine Associated Receptor 1 (TAAR1), TAARs form a possible link between these two systems. Some studies suggest that TAARs are connected to the protein kinase $C$ pathway ${ }^{29}$ and could be influenced by the intracellular signaling from cortisol-induced GR complexes. However, further studies need to be conducted to explore this connection.

\section{Cognitive skills}

In addition to the role which stress plays in limiting motor functions, cognitive skills also have a substantial impact on athletic performance. Especially in team sports, reacting to and awareness of one's environment contributes to increased performance. Mental presence and awareness throughout an athletic event are often called "being in the zone". So, what is it that at times hinders athletes to put themselves into that mental space?

Stress affects our cognitive behavior. It has an impact on the awareness, decision making, planning, and execution of higher cognitive functions, emotional feedback, and memory function $^{30-32}$. Similar to the effects on motor function, corticosterone (or cortisol) and dopamine are key players in the stress response. As mentioned before, studies have shown that corticosterone binds to glucocorticoid and mineralocorticoid receptors in the brain ${ }^{33}$ whereby literature shows that GRs are not only found in motor centers but 
in many other areas of the brain including the prefrontal cortex ${ }^{30.31}$, which this paper will also focus on.

The prefrontal cortex is responsible for a higher cognitive function, especially the integration of the external input into the already existing memory patterns. Therefore, it makes it possible that we are "working with memory" 32 , which is essential for athletes so that they can rely on their training during competition. An increase in stress-mediated cortisol, therefore, leads to an increased binding to GRs. Butts et $a^{\beta 3}$ showed that stress was related to increased dopamine (DA) efflux in the prefrontal cortex due to a higher GR saturation by cortisol. The relation between stress and impaired cognitive function is widely accepted, however, the exact mechanism is complex and insufficiently researched. Again, the above-mentioned correlation gives a promising hypothesis and leaves room for further studies.

Patients affected by Parkinson's disease often show an impairment of cognitive function in addition to motor dysfunctions. Visual impairment, memory loss, decreased working memory, impaired planning, attention and speed of processing information are typical symptoms ${ }^{34,35}$. Narayanan et $a^{34}$ notes that dopamine therapy does not improve executive functions and that the underlying cause is an inactive prefrontal cortex. Again, dopamine seems to be the key to understanding the underlying mechanisms. The stress-induced increased dopamine levels (because of increased efflux) in the prefrontal cortex are the cause for an impaired cognitive function ${ }^{32,36}$. However, the effector functions of dopamine are highly complex. DA should not only be seen as an inhibitor or activator, but rather as a modulator because it points to both inhibitory and excitatory effects dependent on the concentration ${ }^{32,37}$. DA effects relate in an inverted u-shaped curve to cognitive functions as seen in figure 1.

Too low as well as too high DA concentrations impair prefrontal cortex functions. It has been shown that dopamine receptor activation can alter the perceived importance of an incoming stimulus and influence the brain's decision-making process. Excessive DA levels in the PFC lead to a

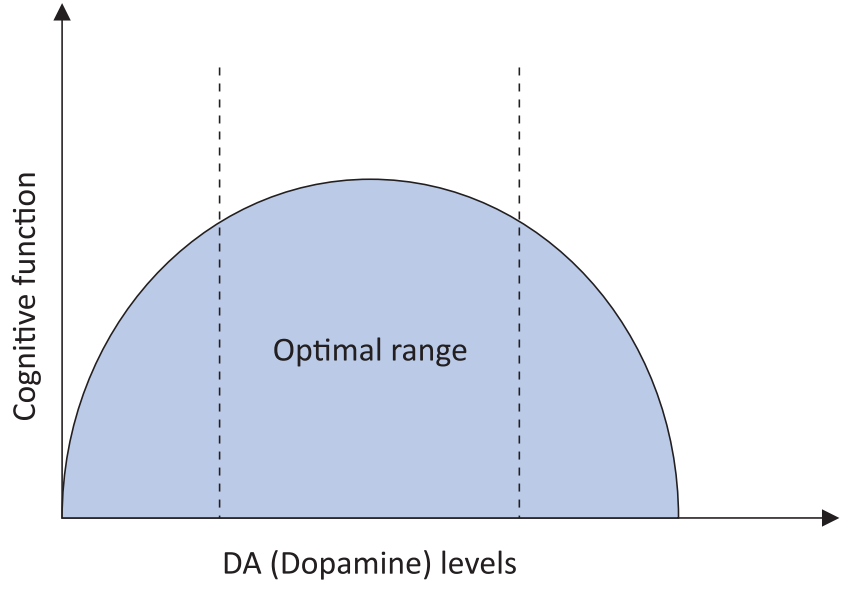

Figure 1. Cognitive functions in relation to dopamine levels in the prefrontal cortex

previous set response, whereas lower DA levels provide the ability to be somewhat more flexible in choosing an appropriate response ${ }^{32}$. Additionally, available literature suggests that not only the concentration but also the baseline function for working memory in each individual and the complexity of the task influence DA effects ${ }^{37}$.

Dopamine binds to a metabotropic, G protein-coupled type receptor ${ }^{32}$, which is slow-acting and triggers multiple intra- and intercellular mechanisms. Intracellular signaling can be $\mathrm{G}$ protein-coupled, like the CAMP/PKA pathway, or G protein-independent. There are five subgroups of dopamine receptors (D1-D5) with D1 being the most relevant one. The exact distribution of the receptors has yet to be determined, but studies have shown that D1 receptors are found on dendrites of pyramidal neurons as well as on GABAergic neurons and, therefore, have the possibility to cause both excitatory and inhibitor effects ${ }^{32}$. Three pathways seem to be most relevant for the inhibitor function of DA. 1) Increased DA receptor saturation leads to decreased N-methyl-D-aspartate (NMDA) levels which usually act excitatory on the neuron. Decreased NMDA leads to a lower excitatory postsynaptic potential (EPSP) and interferes with signal transduction. 2) Increased DA decreases the intracellular calcium current and interferes with signal transduction from the dendrites to the soma and also impairs 
signal integration and transduction. Dopamine receptor activation can open (via PKA) or close (via PKC) L-type calcium channels, where the action is time-dependent. 3) Excessive DA activates GABA excreting interneurons and inhibits the overall signal transduction ${ }^{32,37}$. Seamansa and Yang ${ }^{32}$ show that the GABA release in the prefrontal cortex is very complex and dependent on the stimulation of D1 and D2 dopamine receptors, with D1 increasing presynaptic GABA efflux. Additionally, DA can act on subunits of postsynaptic GABA receptors, altering their function via protein kinase $A$ or $C$ pathways.

It can be stated that stress and its effect on cognitive mechanisms and the prefrontal cortex use cortisol and dopamine as the main effector substances. Dopamine showing highly complex mechanisms in the brain explaining why cognitive skills and intense stress show an inverse relationship.

\section{Metabolism}

\section{Glucose levels}

Well-adapted metabolic functions are necessary to fuel an athlete during physical performance. Adequate energy levels are important for appropriate tissue function. Carbohydrates, fats, and proteins are the main energy sources for the human body. During physical exercise, the musculature depends on fatty acid metabolism as well as glucose $^{38}$. The dominant mechanism for glucose availability is dependent on sympathetic activity. With increased physical strain, the sympathetic nervous system becomes activated and releases catecholamines such as epinephrine, which stimulate glucagon secretion from pancreatic alpha cells and result in increased glycogenolysis ${ }^{39}$. That makes it possible to use the glycogen storage within the muscles or the liver. The glucagon release is catecholamine-dependent and starts with the stimulation of $\beta$-adrenergic receptors on the cell surface. $\beta$-adrenergic receptor stimulation then results in high intracellular cAMP levels, which, in return activates PKA and the exchange protein directly activated by CAMP, isoform 2 (EPAC2). EPAC2 triggers nicotinic acid adenine dinucleotide phosphate (NAADP) release, which is needed to stimulate calcium release in addition to PKA stimulation. PKA acts on two pore channels (Tpc2) on acidic vessels and trigger intracellular calcium release. The released calcium then additionally activates the ryanodine receptors on the endoplasmic reticulum, which releases even more calcium into the plasma. High intercellular calcium levels result in the glucagon release, which then acts systemically and increases the glycogenolysis ${ }^{39}$.

In addition to the increased glycogen breakdown, exercise results in an increased blood flow within the muscle due to elevated metabolic demands. Vasodilation is mainly a result of oxygen depletion, but an increased glucose uptake from the blood via glucose transporter type 4 (GLUT 4) receptors can normally also be observed ${ }^{38}$.

Studies have shown that acute psychosocial stress can increase brain metabolism up to $12 \%{ }^{40}$. In order to meet those elevated demands, the brain has a "pull mechanism", which draws energy sources from the periphery. Stress-induced catecholamines increase plasma lactate levels and can decrease plasma insulin levels by inhibiting its release from $\beta$-pancreatic cells ${ }^{41}$. Lactate is a secondary fuel source for the brain and can stay elevated for hours after an induced stressor even without other supplementary energy sources. Additionally, insulin diminishment prevents a glucose uptake in the periphery because fewer GLUT 4 receptors are being expressed making it available for the brain, where it can be taken up by GLUT 1 transporters ${ }^{40,41}$. A study on the Japanese population shows, on the one hand, that stressinduced elevated glucocorticoid levels result in insulin resistance, because fewer GLUT 4 transporters are translocated onto the cell membrane, diminishing thereby the insulin dependent glucose uptake. On the other hand, it has been suggested that GCs also have a direct effect on the insulin-secreting $\beta$-cells in the pancreas leading to further insulin depression ${ }^{42}$. The interaction between the GC cortisol and $\beta$-cells is not well understood but studies suggest that cortisol could have a direct inhibitory effect on insulin secretion due to the GCR on the $\beta$-cells ${ }^{43}$. However, research in this area is contradictory and seems to be dependent on the cortisol concentration as well as stimuli duration. 


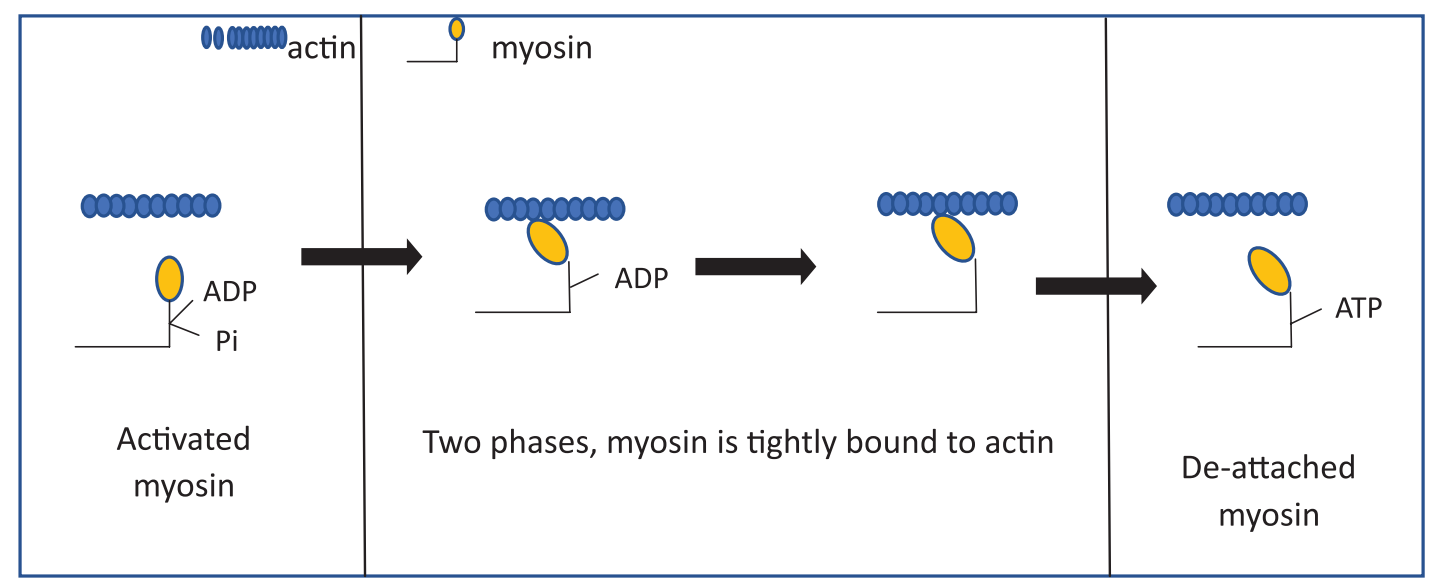

Figure 2. Stages of the myosin-actin crossbridge cycle

The stress-induced metabolic demands of the brain and the glucose pull from the periphery could indicate a peripheral blood glucose depletion. This could have a negative influence on the muscle metabolism since intensive muscular activity relies on the blood glucose as a fuel source and, therefore, decreases the muscular function and athletic performance. However, this relation is hypothetical and requires further research.

\section{Lactate}

Since 1920, blood lactate levels have been known to reduce athletic performance. During heavy exercise, lactate accumulates in the body due to the anaerobic metabolism of pyruvate, causing an acidosis in the muscle. The resulting increased concentration of hydrogen ions interferes with the crossbridge cycling in the skeletal muscle and decreases its contractility ${ }^{44}$.

Figure 2 shows the different stages of the crossbridge cycle. When the myosin-bound adenosine triphosphate (ATP) dissociates into adenosine diphosphate (ADP) and phosphate ( $\mathrm{Pi}$ ) the "pull movement" of the myosin arm occurs and actin slides along myosin, this is followed by two phases, where actin and myosin are still tightly bound to each other. During the first phase, ADP is still bound to myosin and its release seems to depend on ATPase activity. The second phase is the time between the ADP release and the new ATP binding to the myosin chain. Once the new ATP is bound to myosin, the crossbridge is released and a new cycle can begin. Increased $\mathrm{H}^{+}$concentrati- ons seem to interfere with ATPase activity and prolong the first phase, where ADP is still bound. Therefore, acidosis can slow down muscle contraction by up to $30 \%$. Another suggested mechanism is that hydrogen ions change the calcium-binding site on troponin and decrease the calcium sensitivity of troponin and negatively influence muscle contraction ${ }^{45}$.

By contrast, new studies have shown that lactate might have a positive effect on performance in aerobe conditions. If lactate is produced in response to sympathetic stimulation and the athlete is not experiencing oxygen deprivation yet, lactate could actually be used as an additional fuel source $^{44,46}$. Therefore, in sports that mainly use aerobe metabolism throughout the competition, increased lactate levels due to anxiety might not be a negative factor.

It has been shown that, in addition to physiological stress, psychological stress also elevates plasma lactate levels ${ }^{41,47}$. In those stress situations, lactate is increased to meet the elevated metabolic needs of the brain ${ }^{41}$. However, psychologically induced elevation is not as strong as the elevation during physical exercise ${ }^{47}$. Stress increases plasma catecholamine levels ${ }^{41,48}$, which, in return, is related to increased lactate production and release from skeletal muscle ${ }^{46,49}$. Plasma epinephrine and norepinephrine seem to be a result of increased release at the synapses, with epinephrine being more relevant in lactate producti$\mathrm{on}^{49}$. Epinephrine then stimulates $\beta 2$-adrenergic 
receptors ${ }^{46,49}$ on the muscle cell, which leads to intracellular signaling and lactate production. $\beta 2$ adrenergic receptors activate CAMP and increase glycolysis and glycogenolysis. The resulting increase in intracellular ATP stimulates the $\mathrm{Na}+\mathrm{K}+\mathrm{AT}$ Pase and produces more ADP. Increased ADP then leads to increased lactate via phosphofructokinase stimulation and pyruvate production ${ }^{50}$. It can therefore be stated that anxiety and the sympathetic response can increase lactate levels in the blood, which could potentially have a negative effect on performance. Elevated blood lactate level due to anxiety prior to the actual physical performance could diminish an athlete's lactate tolerance by bringing him/her closer to the lactate threshold, which in the end, might lead to lower performance levels.

\section{CONCLUSION}

The aim of this manuscript was to provide an overview of multiple correlations between stress and the body's biochemical response. Strong, sport-related anxiety can alter a person's biochemistry via the sympathetic response and negatively influence fine motor skills, cognitive skills, and metabolic functions. Here, sport psychology can be a great tool to improve an athlete's relative performance and control the negative outcomes of intense stress. This shows the importance of mental training in elite athletes and why it is essential for them to reduce anxiety levels to an optimum level. It can be concluded that a person's mindset is a crucial factor when it comes to physical performance given that how we perceive our emotions directly influences our performance ${ }^{51}$. In order to control the negative effects which anxiety can have on performance, it is important to control anxiety levels in athletes. Placebo studies show that our mind has the power to change our body biochemical processes, which might be used to eliminate the performance limiting factors of anxiety. Reducing stress levels as well as rethinking them seem to be effective methods in sport psychology. Recent studies have shown that reappraising anxiety as excitement, instead of trying to lower anxiety levels, is a more effective strategy ${ }^{51,52}$. Turning perceived stress into something positive can change a person's biological response in a way that will not negatively influence athletic performance. Therefore, combining the current knowledge of placebo effects, stress-related biochemistry, and sport psychology can provide a better insight into athletic performance. This could be used by elite athletes and their training staff to improve performance as well as to reduce recovery time in the aftermath of an injury.

\section{ACKNOWLEDGEMENTS}

Many thanks to professor Matea Butković, PhD for her valuable help in correcting this paper and advices how to achieve a professional writing style.

Conflicts of interest: Authors have no conflicts of interest to declare.

\section{REFERENCES}

1. Howe LC, Goyer JP, Crum AJ. Harnessing the placebo effect: Exploring the influence of physician characteristics on placebo response. Health Psychol. [Internet] 2017 Nov [cited 2020 Apr 5];36:1074-1082. Available from: https://mbl.stanford.edu/sites/g/files/sbiybj9941/f/ howegoyercrum_harnessingtheplaceboeffect.pdf.

2. Crum AJ, Corbin WR, Brownell KD, Salovey P. Mind over milkshakes: mindsets, not just nutrients, determine ghrelin response. Health Psychol. [Internet] $2011 \mathrm{Jul}$ [cited 2020 Apr 5];30:424-9; discussion 430-1. Available from: doi: $10.1037 / \mathrm{a} 0023467$.

3. Yanagi S, Sato T, Kangawa K, Nakazato M. The Homeostatic Force of Ghrelin. Cell Metab [Internet]. 2018 Apr 3 [cited 2020 Mar];27:786-804. Available from: https:// www.cell.com/action/showPdf?pii=S1550-4131\% 2818\%2930119-0.

4. Cabral A, López Soto EJ, Epelbaum J, Perelló M. Is Ghrelin Synthesized in the Central Nervous System? Int J Mol Sci [Internet]. 2017 Mar 15[cited 2020 Mar];18:638. Available from: https://www.ncbi.nlm.nih.gov/pmc/articles/PMC5372651/.

5. Kojima M, Kangawa K. Ghrelin: more than endogenous growth hormone secretagogue. Ann N Y Acad Sci [Internet]. $2010 \mathrm{Jul}$ [cited 2020 Apr];1200:140-8. Available from: doi: 10.1111/j.1749-6632.2010.05516.x.

6. Schaller G, Schmidt A, Pleiner J, Woloszczuk W, Wolzt M, Luger A. Plasma ghrelin concentrations are not regulated by glucose or insulin: a double-blind, placebo-controlled crossover clamp study. Diabetes [Internet]. 2003 Jan [cited 2020 Apr 16];52:16-20. Available from: doi: 10.2337/diabetes.52.1.16.

7. Gagnon J, Anini Y. Insulin and norepinephrine regulate ghrelin secretion from a rat primary stomach cell culture. Endocrinology [Internet]. 2012 Aug [cited 2020 Apr];153:3646-56. Available from: doi: 10.1210/ en.2012-1040.

8. Slade E, Williams L, Gagnon J. Hydrogen sulfide suppresses ghrelin secretion in vitro and delays postprandi- 
al ghrelin secretion while reducing appetite in mice. Physiol Rep [Internet]. 2018 Sep [cited 2020 Apr]; 6:e13870. Available from: doi: 10.14814/phy2.13870.

9. Perello M, Dickson SL. Ghrelin signalling on food reward: a salient link between the gut and the mesolimbic system. J Neuroendocrinol [Internet]. 2015 Jun [cited 2020 Apr];27:424-34. Available from: https://www.ncbi.nlm. nih.gov/pmc/articles/PMC5033008/

10. Gee CJ. How does sport psychology actually improve athletic performance? A framework to facilitate athletes' and coaches' understanding. Behav Modif [Internet]. 2010 Sep [cited 2020 Mar 5];34:386-402. Available from: doi: 10.1177/0145445510383525.

11. Dehghani M, Saf AD, Vosoughi A, Tebbenouri G, Zarnagh HG. Effectiveness of the mindfulness-acceptance-commitment-based approach on athletic performance and sports competition anxiety: a randomized clinical trial. Electron Physician [Internet]. 2018 May 5 [cited 2020 Mar 8]; 10:6749-6755. Available from: doi: 10.19082/6749.

12. Crewther BT, Thomas AG, Stewart-Williams S, Kilduff LP, Cook CJ. Is salivary cortisol moderating the relationship between salivary testosterone and hand-grip strength in healthy men? Eur J Sport Sci [Internet]. 2017 Mar [cited 2020 Apr]; 17:188-194. Available from: doi: 10.1080/ 17461391.2016.1220628.

13. El Zein $M$, Wyart V, Grèzes J. Anxiety dissociates the adaptive functions of sensory and motor response enhancements to social threats. Elife [Internet]. $2015 \mathrm{Dec}$ 29 [cited 2020 Apr];4:e10274. Available from: doi: 10.7554/elife.10274.

14. McIntyre CK, Roozendaal B. Adrenal Stress Hormones and Enhanced Memory for Emotionally Arousing Experiences. In: Neural Plasticity and Memory: From Genes to Brain Imaging. Boca Raton (FL): CRC Press/Taylor \& Francis; 2007. Chapter 13.

15. Taverniers J, Van Ruysseveldt J, Smeets T, von Grumbkow J. High-intensity stress elicits robust cortisol increases, and impairs working memory and visuo-spatial declarative memory in Special Forces candidates: A field experiment. Stress [Internet]. 2010 Jul [cited 2020 Apr]; 13:323-33. Available from: doi: 10.3109/10253891003642394.

16. Dhabhar FS. The short-term stress response - Mother nature's mechanism for enhancing protection and performance under conditions of threat, challenge, and opportunity. Front Neuroendocrinol [Internet]. 2018 Apr [cited 2020 Apr];49:175-192. Available from: https:// www.ncbi.nlm.nih.gov/pmc/articles/PMC5964013/.

17. Anderson GS, Di Nota PM, Metz GAS, Andersen JP. The Impact of Acute Stress Physiology on Skilled Motor Performance: Implications for Policing. Front Psychol [Internet]. 2019 Nov 7 [cited 2020 Apr];10:2501. Available from: doi: 10.3389/fpsyg.2019.02501.18.

Pageaux B, Lepers R. The effects of mental fatigue on sport-related performance. Prog Brain Res [Internet]. 2018 [cited 2020 Apr];240:291-315. Available from: doi: 10.1016/bs.pbr.2018.10.004.

19. Khan, Khushdil \& Khan, Alamgir \& Khan, Salahuddin. Effects of Anxiety on Athletic Performance. Research \& Investigation in Sports Medicine [Internet]. 2017 Oct [cited $2020 \mathrm{Apr}$ ]; 7.1.1-5. Available from: https://crimsonpublishers.com/rism/pdf/RISM.000508.pdf.

20. Lundberg U. Psychophysiology of work: stress, gender, endocrine response, and work-related upper extremity disorders. Am J Ind Med [Internet]. 2002 May [cited
2020 Apr];41:383-92. Available from: doi: 10.1002/ ajim. 10038.

21. Roatta S, Farina D. Sympathetic actions on the skeletal muscle. Exerc Sport Sci Rev [Internet]. 2010 Jan [cited 2020 Apr];38:31-5. Available from: doi: 10.1097/ JES.0b013e3181c5cde7.

22. Wixted, Fiona \& O'Sullivan, Leonard. Effect of attention demand on upper trapezius muscle activity - A moderated mediation model. International Journal of Industrial Ergonomics [Internet]. 2018 July [cited 2020 Apr]; 66. 146-156. Available from https://dl.uswr.ac.ir/bitstream/ Hannan/57898/1/2018\%20IERGONO\%20Volume\%20 $66 \% 20 J u l y \% 20 \% 2813 \% 29$.pdf.

23. Metz GA, Jadavji NM, Smith LK. Modulation of motor function by stress: a novel concept of the effects of stress and corticosterone on behavior. Eur J Neurosci [Internet]. 2005 Sep [cited 2020 May];22:1190-200. Available from: doi: 10.1111/j.1460-9568.2005.04285.x.

24. Oakley RH, Cidlowski JA. The biology of the glucocorticoid receptor: new signaling mechanisms in health and disease. J Allergy Clin Immunol [Internet]. 2013 Nov [cited 2020 May];132:1033-44. Available from: doi: 10.1016/j.jaci.2013.09.007.

25. Groeneweg FL, Karst H, de Kloet ER, Joëls M. Mineralocorticoid and glucocorticoid receptors at the neuronal membrane, regulators of nongenomic corticosteroid signalling. Mol Cell Endocrinol [Internet]. 2012 Mar 24 [cited 2020 May];350:299-309. Available from: doi: 10.1016/j.mce.2011.06.020.

26. Smith LK, Jadavji NM, Colwell KL, Katrina Perehudoff S, Metz GA. Stress accelerates neural degeneration and exaggerates motor symptoms in a rat model of Parkinson's disease. Eur J Neurosci [Internet]. 2008 Apr [cited 2020 May];27:2133-46. Available from: https://onlinelibrary. wiley.com/doi/abs/10.1111/j.1460-9568.2008.06177.x

27. Metz GA. Stress as a modulator of motor system function and pathology. Rev Neurosci [Internet]. 2007 [cited 2020 May];18:209-22. Available from: doi: 10.1515/ revneuro.2007.18.3-4.209.

28. Wheeler DS, Ebben AL, Kurtoglu B, Lovell ME, Bohn AT, Jasek IA, Baker DA, Mantsch JR, Gasser PJ, Wheeler RA. Corticosterone regulates both naturally occurring and cocaine-induced dopamine signaling by selectively decreasing dopamine uptake. Eur J Neurosci [Internet]. 2017 Nov [cited 2020 May];46:2638-2646. Available from: https://pubmed.ncbi.nlm.nih.gov/28965353/.

29. Miller $\mathrm{GM}$. The emerging role of trace amine-associated receptor 1 in the functional regulation of monoamine transporters and dopaminergic activity. J Neurochem [Internet]. 2011 Jan [cited 2020 May];116:164-76. Available from: https://www.ncbi.nlm.nih.gov/pmc/articles/ PMC3005101/.

30. Sandi C. Stress and cognition. Wiley Interdiscip Rev Cogn Sci [Internet]. 2013 May [cited 2020 May];4:245-261. Available from: doi: 10.1002/wcs.1222.

31. Starcke K, Wolf OT, Markowitsch HJ, Brand M. Anticipatory stress influences decision making under explicit risk conditions. Behav Neurosci [Internet]. 2008 Dec [cited 2020 May];122:1352-60. Available from: doi: 10.1037/ a0013281.

32. Seamans JK, Yang CR. The principal features and mechanisms of dopamine modulation in the prefrontal cortex. Prog Neurobiol [Internet]. 2004 [cited 2020 May];74:1-58. Available from: doi: 10.1016/j.pneurobio.2004.05.006. 
33. Butts KA, Weinberg J, Young AH, Phillips AG. Glucocorticoid receptors in the prefrontal cortex regulate stressevoked dopamine efflux and aspects of executive function. Proc Natl Acad Sci U S A [Internet]. 2011 Nov 8 [cited 2020 May];108:18459-64. Available from: https:// www.ncbi.nlm.nih.gov/pmc/articles/PMC3215005/pdf/ pnas.201111746.pdf.

34. Narayanan NS, Rodnitzky RL, Uc EY. Prefrontal dopamine signaling and cognitive symptoms of Parkinson's disease. Rev Neurosci [Internet]. 2013 [cited 2020 May];24:26778. Available from: doi: 10.1515/revneuro-2013-0004.

35. Domellöf $M E$, Elgh $E$, Forsgren $L$. The relation between cognition and motor dysfunction in drug-naive newly diagnosed patients with Parkinson's disease. Mov Disord [Internet]. 2011 Oct [cited 2020 May];26:2183-9. Available from: doi: 10.1002/mds.23814.

36. Zahrt J, Taylor JR, Mathew RG, Arnsten AF. Supranormal stimulation of $\mathrm{D} 1$ dopamine receptors in the rodent prefrontal cortex impairs spatial working memory performance. J Neurosci [Internet]. 1997 Nov 1 [cited 2020 May];17:8528-35. Available from: https://pubmed.ncbi. nlm.nih.gov/9334425/.

37. Cools R, D'Esposito M. Inverted-U-shaped dopamine actions on human working memory and cognitive control. Biol Psychiatry [Internet]. 2011 Jun 15 [cited 2020 May];69:e113-25. Available from: https://www.ncbi. nlm.nih.gov/pmc/articles/PMC3111448/.

38. Institute of Medicine (US) Committee on Military Nutrition Research. Food Components to Enhance Performance: An Evaluation of Potential Performance-Enhancing Food Components for Operational Rations. Washington (DC): National Academies Press (US); 1994;11.

39. Hamilton A, Zhang Q, Salehi A, Willems M, Knudsen JG, Ringgaard AK et al. Adrenaline Stimulates Glucagon Secretion by Tpc2-Dependent $\mathrm{Ca}^{2+}$ Mobilization From Acidic Stores in Pancreatic $\alpha$-Cells. Diabetes [Internet\}. 2018 Jun [cited 2020 May];67:1128-1139. Available from: https://www.ncbi.nIm.nih.gov/pmc/articles/ PMC6258900/.

40. Hitze B, Hubold C, van Dyken R, Schlichting $K$, Lehnert $H$, Entringer $S$ et al. How the selfish brain organizes its supply and demand. Front Neuroenergetics [Internet]. 2010 Jun 9 [cited 2020 May];2:7. Available from: doi: 10.3389/ fnene.2010.00007.

41. Kubera B, Hubold C, Otte S, Lindenberg AS, Zeiss I, Krause $\mathrm{R}$ et al. Rise in plasma lactate concentrations with psychosocial stress: a possible sign of cerebral energy demand. Obes Facts [Internet]. 2012 [cited 2020 May];5:384-92. Available from: https://pubmed.ncbi. nlm.nih.gov/22797365/.

42. Kamba A, Daimon M, Murakami H, Otaka H, Matsuki K, Sato E et al. Association between Higher Serum Cortisol Levels and Decreased Insulin Secretion in a General Population. PLoS One [Internet]. 2016 Nov 18 [cited 2020
May];1:e0166077. Available from: https://www.ncbi. nlm.nih.gov/pmc/articles/PMC5115704/.

43. Lambillotte C, Gilon P, Henquin JC. Direct glucocorticoid inhibition of insulin secretion. An in vitro study of dexamethasone effects in mouse islets. J Clin Invest [Internet]. 1997 Feb 1 [cited 2020 May];99:414-23. Available from: doi: $10.1172 / \mathrm{JCl} 119175$.

44. Todd J. Lactate: valuable for physical performance and maintenance of brain function during exercise. Bioscience Horizons: The International Journal of Student Research [Internet]. 2014 June [cited 2020 May]; 7:hzu001. Available from: doi:10.1093/biohorizons/hzu001.

45. Debold EP. Recent insights into muscle fatigue at the cross-bridge level. Front Physiol [Internet]. 2012 Jun 1 [cited 2020 May];3:151. Available from: https:// pubmed.ncbi.nlm.nih.gov/22675303/.

46. Gjedsted J, Buhl M, Nielsen S, Schmitz O, Vestergaard ET, Tønnesen $E$ et al. Effects of adrenaline on lactate, glucose, lipid and protein metabolism in the placebo controlled bilaterally perfused human leg. Acta Physiol (Oxf) [Internet]. 2011 Aug [cited 2020 May];202:641-8. Available from: doi: 10.1111/j.1748-1716.2011.02316.x.

47. Hermann R, Lay D, Wahl P, Roth WT, Petrowski K. Effects of psychosocial and physical stress on lactate and anxiety levels. Stress [Internet]. 2019 Nov [cited 2020 May]; 22:664-669. Available from: doi: 10.1080/10253890.2019. 1610743.

48. Paran E, Neumann L, Cristal N. Effects of mental and physical stress on plasma catecholamine levels before and after beta-adrenoceptor blocker treatment. Eur J Clin Pharmacol [Internet]. 1992 [cited 2020 May];43:115. doi: $10.1007 /$ BF02280747.

49. Qvisth V, Hagström-Toft E, Enoksson S, Bolinder J. Catecholamine regulation of local lactate production in vivo in skeletal muscle and adipose tissue: role of -adrenoreceptor subtypes. J Clin Endocrinol Metab [Internet]. 2008 Jan [cited 2020 May];93:240-6. Available from: https://academic.oup.com/jcem/article/93/ $1 / 240 / 2598605$

50. Levy B, Desebbe O, Montemont C, Gibot S. Increased aerobic glycolysis through beta2 stimulation is a common mechanism involved in lactate formation during shock states. Shock [Internet]. 2008 Oct [cited 2020 May];30:41721. Available from: doi: $10.1097 /$ SHK.0b013e318167378f.

51. Brooks AW. Get excited: reappraising pre-performance anxiety as excitement. J Exp Psychol Gen[Internet]. 2014 Jun [cited 2020 May];143:1144-58. Available from: doi: $10.1037 / \mathrm{a} 0035325$

52. Jamieson JP, Nock MK, Mendes WB. Mind over matter: reappraising arousal improves cardiovascular and cognitive responses to stress. J Exp Psychol Gen [Internet]. 2012 Aug [cited 2020 May];141:417-22. Available from: https://www.ncbi.nIm.nih.gov/pmc/articles/ PMC3410434/pdf/nihms324194.pdf. 